\title{
Fighting for the Nuşayrī Soul: State, Protestant Missionaries and the 'Alawis in the Late Ottoman Empire
}

\author{
Necati Alkan \\ Jerusalem
}

\begin{abstract}
Based on their writings, the religious beliefs of the Nuṣayrīs have been studied since the $19^{\text {th }}$ century. But historical knowledge and information about them in the $19^{\text {th }}$ century, based on Ottoman sources has been rather meager. Only in recent years this kind of research intensified. In the Ottoman Empire real interest in the Nuṣayrīs started during the reign of Sultan Abdülhamid II (1876-1909). Due to
\end{abstract}

\footnotetext{
* This research began during my senior fellowship in 2008-2009 at the Research Center for Anatolian Civilizations (RCAC), Koç University, Istanbul. I owe a heartfelt gratitude to the RCAC for the financial support and encouragement. I am grateful to Mrs. Duygu Paçalı, the RCAC librarian, for her constant help with providing literature. My research has then continued in 2009-2011 at the Chair for the History of West Asia, University of Erfurt/Germany (financed by the Bosch Foundation); I would like to thank Prof. Birgit Schäbler and the doctoral students for their remarks at our colloquia. Furthermore, I am particularly beholden to Prof. Dror Zeevi (Ben Gurion University of Negev/BGU), Prof. Şükrü Hanioğlu (Princeton University), Prof. Meir M. Bar-Asher (The Hebrew University of Jerusalem) and Dr. Markus Dressler (Istanbul Teknik Üniversitesi) for reading earlier versions of my paper and making valuable comments. During the World Congress for Middle Eastern Studies (WOCMES) in Barcelona/Spain, 19-24 July 2010, I shared parts of this paper at the "Late Ottoman/Post-Ottoman Heterodox Communities" panel that I co-organized; my lecture was titled "Appropriate objects of christian benevolence?' Protestant Missionaries, the Nusayris and the Ottomans". I am grateful to my co-panelists Dr. Laila Prager, Dr. Sebastian Maisel and Edip Gölbaşı, and the audience for their remarks. Lastly, I had the opportunity to share a shorter version of this paper titled "The Nusayri Awakening in the Late $19^{\text {th }}$ Century" at the Hebrew University of Jerusalem (28 February 2011) and the BGU (2 March 2011). My heartfelt thanks go to Prof. Moshe Sharon, Dr. Meir Hatina and Prof. Dror Zeevi for inviting me and organizing my talks. I also want to express my thanks to the anonymous reviewers of this article.
} 
fear of infiltration of heterodox Muslims by foreigners, especially by American and English Protestant missionaries, the Sultan was pressed to attract them to the Hanafī-Sunnī school. In this process, the status of the Nuṣayrīs underwent changes. After summarizing the attitude of the provincial Syrian administration and of Istanbul toward the Nuṣayrīs in the first decades of the $19^{\text {th }}$ century, the article will give an overview of the developments regarding the Nuṣayrīs during the Tanzimat and the Hamidian era until roughly the Young Turk revolution. The following questions will be asked: How did Protestant missionaries integrate the Nușayrīs into their millenarian belief in a new social order? By what means did the Ottoman pacifying or "civilizing" mission attempt to integrate the Nuṣayrīs? And how did the Nușayrīs respond to the efforts of the Christian missionaries and the Ottoman state? The article will also challenge the view that the name "Alawī" was only used after 1920 .

\section{Keywords}

Late Ottoman Empire, $19^{\text {th }}$ and $20^{\text {th }}$ centuries, Nuṣayrīs, 'Alawī, heterodoxy, American and English Protestant missions

Throughout the centuries the Nuṣayrīs ('Alawīs), Arabic-speaking members of a gnostic sect with roots in Shīi Islam, who had been living in Ottoman Syria (present-day South Turkey and Syria), have kept their faith secret by living in seclusion owing to fear of persecution by the Sunnī Orthodoxy. The religious beliefs of the Nuṣayrīs have been studied since the $19^{\text {th }}$ century, based on their writings that are now extant in European libraries. ${ }^{1}$ Historical knowledge and information about the Nuṣayrīs in the $19^{\text {th }}$ century, based on Ottoman sources has been rather meager. Only in recent years this kind of research intensified. ${ }^{2}$

1) The most recent publications are Meir M. Bar-Asher and Arieh Kofsky, The Nușayrī'Alawi Religion: An Enquiry into its Theology and Liturgy (Leiden: Brill, 2002); and Yaron Friedman, The Nusayri-'Alawis: An Introduction to the Religion, History and Identity of the Leading Minority in Syria (Leiden: Brill, 2010). For an overview about the Nuṣayrīs, see Heinz Halm, "Nușayriyya", in: $E I^{2}, 8$, pp. 145-148.

2) An important study that does not use Ottoman sources, is Dick Douwes' "Knowledge and Oppression: The Nusayriyya in the Late Ottoman Period”, in: Convegno sul tema La Shia nell'impero ottomano (Roma: Accademia nazionale dei Lincei, Fondazione Leone Caetani, 1993), pp. 149-169. Otherwise the following studies utilize Ottoman archival sources: Selim Deringil, "The Invention of Tradition as Public Image in the Late Ottoman Empire, 1808 to 1908”, in: Comparative Studies in Society and History 35 (1993), pp. 3-29; 
Knowledge of the Nuṣayrīs and similar groups (such as the Druze and the Yezidis) in modern times began with Western travellers, orientalists and missionaries, starting in the late $18^{\text {th }}$ century. These secret sects were studied for learned purposes, sometimes to bring them into the fold of Christianity but also to find ways how to exploit them against the Ottomans politically. In the Ottoman Empire real interest in the Nuṣayrīs started during the reign of Sultan Abdülhamid II (18761909). The fear of infiltration of heterodox Muslims by foreigners, especially by American and English Protestant missionaries, pressed the Sultan to attract them by educative means to the official Hanafī-Sunnī school. In this process, the status of the Nuṣayrīs changed during the late $19^{\text {th }}$ century as a result of the missionary attempt to convert them and the Ottoman fear that they would become another "European problem" for them to deal with. A fight for the Nuṣayrī soul began that left them changed.

Before I discuss these efforts by the missionaries and the Ottoman counter-propaganda, I will summarize the attitude of the provincial Syrian administration and of Istanbul toward the Nuşayrīs in the first decades of the $19^{\text {th }}$ century, before the Tanzimat ("reform") period

İlber Ortaylı, "19. Yüzyılda Heterodox Dinî Gruplar ve Osmanlı İdaresi”, in: İslâm Araştırmaları Dergisi, I/1 (İstanbul 1996), pp. 63-68, republished in: idem, Batılılaşma Yolunda (Istanbul: Merkez Kitaplar, 2007), pp. 156-160; idem, "Alevilik, Nusayrîlik ve Bâbıâli”, in: Tarihî ve Kültü̈rel Boyutlariyla Türkiye'de Alevîler, Bektaşiler, Nusayrîler (Istanbul: Ensar Neşriyat, 1999), republished in Batılılaşma Yolunda, pp. 161-169; Stefan Winter, "La révolte alaouite de 1834 contre l'occupation égyptienne: perceptions alaouites et lecture ottomane", in: OM 79-3 (1999), pp. 61-71; idem, "The Nusayris before the Tanzimat in the Eyes of Ottoman Provincial Administrators, 1804-1834”, in: Thomas Philipp/Christoph Schumann (eds.), From the Syrian Land to the States of Syria and Lebanon (Würzburg: Ergon, 2004), pp. 97-112. Most recent contributions are by Yvette Talhamy, Meridot ha-Nusayrim ('Alawim) be-Surya be-me'a ha-tesha' 'esre (in Hebrew: "The Nusayriyya Uprisings in Syria in the $19^{\text {th }}$ Century") (Ph.D. thesis, University of Haifa, 2006); idem, "The Nusayri Leader Isma'il Khayr Bey and the Ottomans (1854-58)", in: MES 44 (2008), pp. 895-908; idem, "American Protestant Missionary Activity among the Nusayris (Alawis) in Syria in the Nineteenth Century", in: MES 44 (2011), pp. 215-236; idem, "Conscription among the Nusayris ('Alawis) in the Nineteenth Century”, in: BRISMES 38 (2011), pp. 23-40. See also the Nușayrī issue of Hacı Bektaş Veli Araştırma Dergisi (henceforth HBVAD), Bahar/ Spring 2010, no. 54, online at http://www.hbvdergisi.gazi.edu.tr/index.php? module=dergið sayi $=54$ \&lang $=\operatorname{tr}$ (accessed 24 January 2011). 
(1839-1876). Following this I will provide an overview of the developments regarding the Nuṣayrīs during the Tanzimat and the Hamidian era until roughly the Young Turk revolution.

Overall, in this paper we will look into the missionary and Ottoman attitude toward the Nuṣayrīs and examine topics such as resistance, assimilation, integration and conversion. I shall attempt to answer the following questions: How did Protestant missionaries integrate the Nuṣayrīs into their millenarian belief in a new social order? By what means did the Ottoman pacifying or "civilizing" mission attempt to integrate the Nuṣayrīs? And how did the Nuṣayrīs respond to the civilizing efforts of the Christian missionaries and the Ottoman state?

As I am aware that the word "Nuṣayrî" has a negative connotation, I nevertheless use it as it appears in Ottoman documents and other sources before 1920. It is widely accepted that only from that date onward the Nuṣayrīs named themselves "Alawīs" (followers of Imam 'Alī) to shake off any hint of heresy and to prove that they belong to Shīi I Islam, as the fifth Islamic legal school. I am, however, challenging the widely accepted view that the name "Alawi”" was only used after 1920. A study of Ottoman archival documents of the late $19^{\text {th }}$ century reveals the opposite.

\section{The Early $19^{\text {th }}$ Century}

The Ottoman Empire was a conglomerate of officially recognized religions as well as secretive and officially not recognized sects within and outside Judaism, Christianity and Islam. These sects not only concealed their beliefs but sometimes did not accept the official religion or mainstream beliefs. Even though non-Sunnī religious minorities within Islam were not regarded as non-Muslims, they were labeled "heretical" (rā $f i \dot{z} \bar{\imath})$ and largely ostracized by the Sunnī clergy and people. Within the Muslim community such "heretics" were the Shī îs, Alevis, Yezidis and the Nuṣayrīs ('Alawīs). These were creeds seen as deviant of the caliphal Hanafī-Sunnī dynasty and had no official status as autonomous religious communities (millet).

In the first three decades of the $19^{\text {th }}$ century we see efforts of the Ottoman administration to treat the Nuṣayrīs, alongside Yezidis and 
"Kızılbaş" (the Shīisis of Lebanon), as political scapegoats. They were linked with rebellions incited by local governors in Syria or accused of collaboration with the Greek who during their nationalist revolt in the 1820s supposedly tried to unite heterodox sects against the Muslims. At the same time, governors in Syria, who were hostile toward each other, showed leniency toward the Nuṣayrīs and similar groups and proposed their pacification in an attempt to win them as allies. ${ }^{3}$

On the other hand, Nuṣayrīs especially in northern Syria, in and around Antakya, were regarded as loyal citizens who did not engage in banditry but pursued their living as farmers or townsmen. It appears that the Nuṣayrīs of this region are almost not mentioned in official Ottoman documentation until after the second half of the $19^{\text {th }}$ century. This may have been the elegant way the Ottomans chose to allow these people to exist and contribute to society while officially not recognizing their religious preferences, as a way to overcome political dissonances in their realm. But even the Nuṣayrīs of the South, living in the Nușayriyya Mountains near the coast city Latakia (Lazkiye), people who supported their insufficient agricultural income with brigandage, could appear as loyal subjects. In fact, in this period these Nuṣayrīs are described by European travellers mostly as hard-working and peaceful people. ${ }^{4}$ This gradually changed as a result of the Egyptian occupation of Ottoman Syria by Mehmed Ali Pasha. His son Ibrahim Pasha became governor of Syria and inaugurated economic, administrative and military reforms with the aim of integrating the province into a new Egypt. As part of his program, he began to collect the arms of the local population and enforced general conscription. ${ }^{5}$ Consequently, insurrections occurred, and the Nuṣayrīs incited the first revolt against the Egyptians in $1834 ;^{6}$ they not only refused to disarm and send recruits to the army

\footnotetext{
3) See, e.g., BOA (Başbakanlık Osmanlı Arşivi, Istanbul), HAT 385/20647; HAT 386/20671 and 20671-A; Stefan Winter, "The Nusayris before the Tanzimat", in: Philipp/ Schumann (eds.), From the Syrian Land to the States of Syria and Lebanon, pp. 100-103.

4) L. J. Rousseau, "Memoire sur les Ismaelis et les Nosairis de Syrie", in: Annales des Voyages 14 (1811), p. 300; F. Walpole, The Ansayrii, 3 vols. (London: Bentley, 1851), vol. 3, p. 352; Douwes, "Knowledge and Oppression”, in: Convegno sul tema La Shia, p. 159.

5) For conscription under Mehmed Ali and the Ottomans, see Talhamy, "Conscription".

6) Winter, "La révolte alaouite de 1834", pp. 60-71. It is interesting that around the same time the peasants of Palestine also began a rebellion against the Egyptians; see Joel Beinin,
} 
but also attacked the troops in Latakia and destroyed government buildings. During this decade of Egyptian rule in Syria (1831-1841), the Ottomans supported and armed the Nuṣayrīs against Ibrahim Pasha. ${ }^{7}$ After Ibrahim Pasha and his troops left, the Nușayrīs used their army experience to turn against the Ottomans. However, Ibrahim had managed to break the independency of the Nuṣayrīs and fractured their solidarity. He ensured that the different Nuṣayrī tribes were in strife with each other; his gold had turned Nușayrī against Nușayrī. Later, the Ottomans were not hesitant to use this disunity to their advantage. ${ }^{8}$

Even though the Nuṣayrīs were defeated in their 1834 revolt, the event was reported by a local Ottoman official to the Sublime Porte in favourable and exaggerated terms, stating that the "numerous and powerful" Nușayrīs were strategically successful. Obviously, the writer wanted to further local interests and emphasized that the people in Syria wanted the Ottomans to end Egyptian occupation. The reality was different: whereas the traditional feudal Nuṣayrīs in their mountains were against the Egyptian modernizing reforms and sided with the Ottomans, the Nușayrīs at the Syrian coastal plain appreciated Mehmed Ali's efforts that promised religious equality too. ${ }^{9}$ An Ottoman campaign in Syria against Egypt, which parts of the Syrian population hoped for, did not happen. The discriminatory behaviour toward the Nuṣayrīs after the Egyptians left Syria implies that the Ottomans did not care about their loyalty.

The pre-Tanzimat period does not only have negative aspects regarding the Nuṣayrīs. There are cases of few Nuṣayrīs who served as state functionaries, some attaining high positions. A Nuṣayrī who was a celebrated Ottoman military official was Kara Mehmed Pasha (d. 182829), also called "Kara Cehennem" (Black Hell). A native of Antakya, he was acting as master general of the imperial artillery (among other

\footnotetext{
Workers and Peasants in the Middle East (Cambridge/New York: Cambridge University Press, 2001), p. 34.

7) Talhamy, Meridot ha-Nusayrim, pp. 77-111. I have no copy of Talhamy's thesis in Hebrew, there would also have been a language barrier; I thank her for pointing out the relevant pages and sending me an English summary of her thesis. See also idem, "The Nusayri Leader Isma'il Khayr Bey and the Ottomans (1854-58)", p. 896.

8) Walpole, The Ansayrii, vol. 3, p. 353.

9) Winter, "The Nusayris before the Tanzimat", in: Philipp/Schumann (eds.), From the Syrian Land to the States of Syria and Lebanon, p. 105.
} 
functions) and is said to have bombed the Janissary barracks in 1826 during Sultan Mahmud II's "Auspicious Event" (vak'a-yı khayriyye). While this latter attribution seems to be incorrect, it is certain that Kara Mehmed rose to the rank of full vizier as grand admiral (kapudan- $\iota$ deryā), "the first and only Nuṣayrī ever to achieve that distinction". He is regarded as having been "foresighted" (tedbirli) and was a source of pride for his townsmen and apparently encouraged the migration of Nuṣayrīs to Istanbul and Bursa. ${ }^{10}$ Kara Mehmed had failed to defend a port in Morea during the Greek rebellion (1822) but nevertheless was seen by Mahmud II as "illustrious and capable from among my vezirs, and experienced, hard-working and decorated from among my splendid ministers, in every way deserving of favour and worthy of benevolence" and appointed as governor of the rich province of Ankara and Çankırı. ${ }^{11}$ He was married to the daughter of Halil Hamid Pasha, a former grand vizier. This family connection obviously helped Kara Mehmed's son Mahmud Bey (d. 1841) to serve at the imperial chancery of state. ${ }^{12}$

Another noted Nuṣayrī official was Mehmed Emin Vahid Efendi, who was born in Kilis (southeastern Anatolia) and taken as a child to Istanbul by his mother and subsequently rose to high offices. He was appointed ambassador to France by Sultan Selim III in 1806. Vahid Efendi later became chief accountant (defter emini) at the Imperial Council (Dìvān-ı Hümāyùn) and was appointed governor of Hanya (1819-1820) and Aleppo (1826-1827). He was known as Vahid Mehmed Pasha, the title pasha given to him because he was made vizier. Four times he held this position, but due to laxity or mismanagement it was taken from him three times. Vahid Mehmed Pasha died in 1828 before he set out to Bosnia as new governor. ${ }^{13}$ Among the noteworthy events during Vahid Efendi's ambassadorship in Paris was his

\footnotetext{
10) Ibid., pp. 110f.; Mehmed Süreyyā, Sicill-i 'Osmānī, 6 vols. (Istanbul: Tarih Vakfı Yurt Yayınları, 1996), vol. 4, pp. 1058f.; Muhammad Aminn Ghālib al-Ṭawil, Ta’rīkh al-'Alawiyyīn (reprint; Beirut: Dār al-Andalus, 2000), p. 443; this book was first published 1924 in Latakia; in Turkish translation, Muhammed Emîn Gâlip et-Tavîl, Arap Alevilerin Tarihi: Nusayrîler (transl. İsmail Özdemir; Istanbul: Chiviyazıları, 2000), p. 301.

11) Winter, "The Nusayris before the Tanzimat", in: Philipp/Schumann (eds.), From the Syrian Land to the States of Syria and Lebanon, pp. $110 \mathrm{f}$.

12) Süreyyā, Sicill-i 'Osmānī, vol. 3, p. 909.

13) Ibid., vol. 5, pp. 1648f.; see also Bursalı Mehmed Tahir, Osmanlı Müellifleri (Istanbul, 1343/1924-25), vol. 3, p. 160.
} 
encounter with Napoleon Bonaparte. He describes this in his Embassy Diary (Sefäretnāme-yi Firansā). ${ }^{14}$

Kara Mehmed and Vahid Mehmed Pasha are identified by Mehmed Süreyya (d. 1909), a biographer of Ottoman officials, as Nuṣayrīs without any negative connotation. Of course one cannot be sure whether the above mentioned Nuṣayrīs became important officials due to the tolerance of the Ottomans or simply because they hid their Nuṣayrī identity.

In contrast to this official Ottoman stance is the attitude of the famous statesman and historian Ahmed Cevdet Pasha (d. 1895) as an example of the opinions about "heretical" groups among conservative Muslim statesmen in the Tanzimat period. He made derogatory remarks about his rival Fuad Pasha's wife's family from Antakya, writing that although Fuad knew about her family's too lax moral behaviours he would remain blind to this because his wife and his father-in-law were Nușayrīs and this group (ța $\left.\bar{a}^{\prime} f e\right)$ did not care about morals. ${ }^{15}$ Cevdet Pasha writes in the same vein about the Nuṣayrī in his Tärìkh-i Cevdet, sometimes based on hearsay. He says that the Nuṣayrīs live in the mountains of Syria and Tripoli, talks about their "fallacious" (bätıll) creed and ends the discussion with the Arabic expression hafazna llähu min shurüri 'aqā'idibim ("God save us from the evils of their beliefs"). ${ }^{16}$

\section{The Tanzimat and its Aftermath}

Despite the atmosphere of proclaimed religious tolerance in the Ottoman capital in the context of the Tanzimat reforms, the situation in eastern provinces was different. A major example for this was the

\footnotetext{
14) For details, see Yavuz Ercan, "Seyyid Mehmed Emin Vahid Efendi'nin Fransa Sefaretnamesi", in: Osmanl Tarihi Araştırma ve Uygulama Merkezi Dergisi, Ankara Üniversitesi, 1991, no. 2, pp. 73-125, online at http://dergiler.ankara.edu.tr (accessed 3 May 2010).

15) Ahmed Cevdet Pasha, Maruzat, ed. by Yusuf Halaçoglu (Istanbul: Çağrı Yayınları, 1980), p. 2.

16) Idem, Tarih-i Cevdet, vol. 1 (Dersaadet [Istanbul], 1309/1891-92), pp. 332ff.; for the issue see Ortaylı, "19. yüzyılda heterodox dinî gruplar ve Osmanlı idaresi”, in: idem, Batılılaşma Yolunda, pp. 156-161 and idem, "Alevîlik, Nusayrîlik ve Bâbıâlî", in: ibid., pp. 161-169.
} 
conflict between the Sunnī Ottomans and Shīī Iranians in Iraq. Shīī clerics were actively proselytizing not only among Sunnī tribes but also among Ottoman officials. ${ }^{17}$ During the Tanzimat but especially also in later years the Ottomans pursued a policy of "Sunnitization" of heterodox communities as anti-propaganda. The aim was to indoctrinate "heretical" sects with the orthodox doctrines of the Hanafi legal school. This was called taşhīh-i 'aqā'idli'tiqäd or "correction of beliefs", in other words, a "fine tuning" of religious beliefs of those who had inherited the idea of Islam from their ancestors and were Muslims merely by name. ${ }^{18}$

Tașhīh-i 'aqā'idli'tiqäd was not a new concept; it was already mentioned after the violent abolition of the Janissaries in 1826. People identified as Bektaşis (members of a Sufi order with Shīi ì leanings), who had associated with the Janissaries and led them spiritually for centuries, were persecuted. Those who were sent into exile could enjoy amnesty, provided that they "corrected" their beliefs and became Sunnīs. ${ }^{19}$

Being regarded as nominal Muslims, the Nuṣayrīs were target to different Ottoman policies. From 1840 to 1880 conflicts and banditry increased in the Nușayriyya (Anșāriyya) Mountains. Disagreements between Nuṣayrī tribes were not the only cause for this. Almost every year Ottoman troops carried out punitive expeditions in the Mountains in order to collect taxes, disarm villagers and recruit soldiers. The mountaineers usually refused to pay taxes and to send their sons to the army. ${ }^{20}$

17) Meir Litvak, Shi i Scholars of Nineteenth-Century Iraq: The 'ulema' of Najaf and Karbala' (Cambridge: Cambridge University Press, 1998), pp. 128-134, 140ff.; Yitzhak Nakash, "The Conversion of Iraq's Tribes to Shiism", in: IJMES 26 (1994), pp. 443-463.

18) Selim Deringil, The Well-Protected Domains: Ideology and the Legimation of Power in the Ottoman Empire, 1876-1909 (London/New York: I.B. Tauris, 1998), pp. 68-92; idem, "The Struggle Against Shi' ism in Hamidian Iraq", in: WI 30 (1990), pp. 45-62; Gökhan Çetinsaya, "The Caliph and Mujtahids: Ottoman Policy towards the Shiite Community of Iraq in the Late Nineteenth Century", in: MES 41 (2005), pp. 561-574; Ortayl1, "19. yüzyılda heterodox dinî gruplar ve Osmanlı idaresi”, in: idem, Batılllaşma Yolunda, pp. 156161 and idem, "Alevîlik, Nusayrîlik ve Bâbıâlî", in: ibid., pp. 161-169.

19) BOA, HAT 512/25094-D, 25 Rebiülevvel 1249/12 August 1833; Muharrem Varol, Bektaşiliğin İlgası Sonrasında Osmanlı Devletinin Tarikat Politikaları 1826-1866 (Ph.D. thesis, Marmara Üniversitesi, Istanbul, 2011), pp. 407, 410.

20) Douwes, "Knowledge and Oppression", in: Convegno sul tema La Shia, p. 160. Resistance against the paying of taxes is recorded as early as 1757; when Nuṣayrī tribes chased the tax 
Nuṣayrīs living in the coastal plain were integrated into the provincial administration and tied to local notables but the increase of raids by Ottoman troops forced many of them to move northwards or to the plains of Hums and Hama where they cultivated the lands. ${ }^{21}$ Emigration of Nuṣayrīs from south to north to the Adana-Çukurova region seems to have commenced in the beginning of the $19^{\text {th }}$ century, due to better economic prospects and religious discrimination. ${ }^{22}$

Although the Nușayrīs were not seen as Muslims in terms of creed and denied official legal status, they were included in the Muslim millet in the formal censuses, not treated as non-Muslims and did not pay the poll-tax (jizya). In the early Ottoman period in Syria they had to pay a capital tax (dirham al-rijäl). ${ }^{23}$ In our period under discussion no documents could be found confirming the payment of this tax but the fact that the Nuṣayrīs were considered apostates may have influenced the tax assessment. The Ottomans put heavy taxes on the lands where Nușayrīs worked as farmers, even though it remains unclear whether this was based on religious grounds. Theoretically, albeit Islamic law did not tolerate apostates, it did not have a basis for an unfair fiscal burden. ${ }^{24}$

Despite that the Nuṣayrīs constituted two-third of the population in the region of Latakia and elsewhere, they did not have their representatives in the regional council. Both Muslims and Christians disliked them, to say the least, and opposed the idea of the official representation of those peasants whom they regarded as hiding their beliefs, and

officers (mübaşir) and sent a letter of warning to the governor Abdulrahman Pasha, saying that he should not oppress the people; see BOA, MD 160/73-1, mentioned by Mesut Aydıner, "Sinek Sözüyle İş̧ Yapan Pâdişahın Hâli Ya Da Karaman Valisi Darendeli Sarı Abdurrahman Paşa İsyanı”, in: Selçuk Üniversitesi Sosyal Bilimler Enstitüsü Dergisi 16 (2006), pp. 785-789, here p. 789, n. 16, online at http://www.sosyalbil.selcuk.edu.tr/sos_mak/ articles/2006/16/MAYDINER.PDF (accessed 3 May 2010).

21) Douwes, "Knowledge and Oppression", in: Convegno sul tema La Shia, p. 161.

22) Winter, "The Nuṣayrīs before the Tanzimat", in: Philipp/Schumann (eds.), From the Syrian Land to the States of Syria and Lebanon, pp. $103 \mathrm{f}$.

23) Dick Douwes, The Ottomans in Syria: A History of Justice and Oppression (London/New York: I.B. Tauris, 2000), p. 142; Ahmet Akgündüz, "Mâzi Penceresinden Düşünce Hürriyeti", online at http://www.osmanli.org.tr/belgelergerceklerikonusuyor-2-95.html (accessed 5 May 2009).

24) Douwes, The Ottomans in Syria, pp. $142 \mathrm{f}$. 
as being rebellious and immoral. In some places such as $\mathrm{Hama},{ }^{25}$ Adana and Tarsus the Nușayrīs were allowed by the authorities to make use of the sharīa courts for legal matters (Nusayriler ehl-i İslämin ḥukuk-i şer'iyyesinden tamämuyla hișsedār olarak).$^{26}$ But overall this issue remains vague. As apostates the Nuṣayrīs had no legal rights; they could not claim any right at the Islamic and secular regulation courts and their testimony there was not heeded (işbu țā'ifenin mahkeme-yi şer'iyye ve-nizāmiyyede öteden beri şehädetleri istimā' ettirilmediğinden). ${ }^{27}$ It seems that only in some cases they were allowed to witness against Muslims and Christians. ${ }^{28}$ With the reform period and the secularization of the civil code of laws in the Ottoman Empire, the Nuṣayrīs had a more secure legal status. Owing to increasing European intervention, for example in the Balkans and with the Armenians in Anatolia, and the fear that the Great Powers could also "protect" the Nuṣayrīs, the authorities were more inclined to include them in the Muslim millet. Another factor in this context was the increase in missionary efforts of American Protestants among the Nuṣayrīs and similar groups especially after the 1850 s. $^{29}$

\section{Protestant Missionaries, the Nuṣayrīs and the Ottomans}

The ill-treatment of the Nuṣayrīs by the majority of the population and the authorities had aroused the compassion of Christian missionaries who tried to win their souls. Here we will restrict ourselves to the views and experiences of American Protestant missionaries toward the Nușayrīs. When the first two missionaries, the young reverends Pliny Fisk and Levi Parsons, were sent to the Ottoman Empire, their chosen

\footnotetext{
25) Ibid., p. 143.

26) BOA, Y.PRK.MF. 2/57, 5 Cemaziyelevvel 1310/24 November 1892, no. 1, p. 3.

27) Same file, no. 1, p. 2.

28) Douwes, The Ottomans in Syria, p. 164; al-Ṭawīl, Ta'rìkh al-'Alawiyyin, pp. 398f.; idem, Arap Alevilerin Taribi, pp. $312 \mathrm{f}$.

29) Douwes, "Knowledge and Oppression", in: Convegno sul tema La Shia, p. 166; Uygur Kocabaşoğlu, Kendi Belgeleriyle Anadolu'daki Amerika: 19. Yüzyzlda Osmanlı Imparatorluğundaki Amerikan Misyoner Okulları (Istanbul: Arba, 1991); see further Ussama Makdisi, Artillery of Heaven: American Missionaries and the Failed Conversion of the Middle East (Ithaca/London: Cornell University Press, 2008).
} 
aim was to convert the people to Protestant Christianity. Information about American Protestant missionaries and their relationship with the Nușayrīs is fairly accessible, firstly, through the journal The Missionary Herald published by the American Board of Commissioners for Foreign Missions (ABCFM). The entries from the years 1819 to 1870 concerning Ottoman Syria were gathered in five volumes and they reproduce firsthand accounts. ${ }^{30}$ While these offer interesting details about the daily life of the missionaries and the people, they are limited in that they do not always offer correct historical information. This stems from the fact that knowledge on Nuṣayrīs was sometimes acquired from biased sources. Nevertheless, in the later decades of the $19^{\text {th }}$ century missionaries (and historians) were able to travel and live among Nuṣayrīs and so wrote about their experiences in letters or books.

The second source for Protestant missionaries and the Nuṣayrīs is official Ottoman records at the Başbakanlık Osmanlı Arşivi (Prime Ministry's Ottoman Archives) in Istanbul. Like the missionary journal entries or books, they only offer one side of the story-the gaze from the Ottoman capital city.

The Protestant missionary movement was commenced for religious purposes first, i.e. the evangelization of the world. It is important to understand the goal of the missionaries' travels to various parts of the world. As Michael Oren states in his book about the relationship of the history of America with the Middle East, there existed from the Pilgrims onwards within American Protestantism a strong emotional attachment to the Israelites of the Hebrew Bible. Parallels were drawn by the Pilgrims between their experiences and those narrated in the Bible, such as the crossing of the Israelites of the Red Sea to escape from the oppression of the Pharaoh in Egypt, likewise did the Pilgrims cross the Atlantic to be far away from King George's England. ${ }^{31}$ This respect for the

\footnotetext{
30) Kamal Salibi/Yusuf K. Khoury (eds.), The Missionary Herald: Reports from Syria 18191870, 5 vols. (Beirut: Royal Institute for Inter-Faith Studies, 1997). In 1870 the mission in Syria was handed over to the Board of Foreign Missions of the Presbyterian Church (BFMPC); see ibid., vol. 5, pp. 253-328; Kocabaşoğlu, Kendi Belgeleriyle Anadolu'daki Amerika, p. 126.

31) Michael Oren, Power, Faith and Fantasy: America in the Middle East, 1776 to the Present (New York: Norton, 2007), p. 85.
} 
ancient Israelites led to a desire to convert contemporary Jews in order to bring them into the "correct" fold and hasten the Second Coming.

Proselytizing was the original and immediate aim of the missionary project, albeit not the only one. With regard to the Protestant missions Hans-Lukas Kieser writes that

In the mid-nineteenth century, the utopia of the Protestant missionaries in Turkey consisted of an almost millenarian belief in a new social and symbolic order, promoted by their own evangelistic, educative, and civilizing efforts, and linking their modern belief in progress with evangelical spirituality. ${ }^{32}$

This was done and inspired by the teachings of their religion and by their patriotism for their young country, and this in turn led to a belief that American ideals should be spread throughout the world. This was also the basis of the Second Awakening (1800-1830), the revivalist or millenarian religious movement that launched the ABCFM. It stressed both a return to religion and a glorification of American democracy and values all over the world. However, as Parsons and Fisk set out for their journey they believed that

while conversions might be made elsewhere in the world, only in Palestine [...] would they have an immediate and millennial impact. Only there would the Protestant's [sic] longing to reunite with their spiritual forebears, the Jews, converge with their yearning for the Messiah's reappearance. ${ }^{33}$

Even though proselytizing the Jews in the Ottoman Empire may have been the real aim, the missionaries were not unconscious of Islam as the dominant religion in the Ottoman Empire and that a substantial number of non-Protestant Christian communities also lived there. Consequently, the ABCFM's representatives also hoped to convert the nonProtestant Christians, the Muslims and the other minorities living in

\footnotetext{
32) Hans-Lukas Kieser, "Some Remarks on Alevi Responses to the Missionaries in Eastern Anatolia (19th-20th cc.)", in: Eleanor H. Tejirian/Reeva Spector Simon (eds.), Altruism and Imperialism. Western Cultural and Religious Missions to the Middle East (19th-20th cc.) (New York: Columbia University, 2002), pp. 120-142 (here p. 120). See also idem, Nearest East: American Millennialism and Mission to the Middle East (Philadelphia: Temple University Press, 2010).

33) Oren, Power, Faith and Fantasy, p. 88.
} 
the different provinces. Owing to the lack of a formal relationship between the USA and the Ottoman Empire, the missionaries set out without knowing one important factor: proselytizing Muslims was illegal in the Ottoman Empire. ${ }^{34}$ This fact probably shocked the missionaries upon their first arrival in the Empire:

The nature of the Turkish government may be considered unfavourable to Christian missionaries. Once Mahomedans were engaged in disseminating their religion by the sword. Then conversion or death was the only alternative offered to those under their power. Now death is the penalty of apostasy from their religion $[\ldots]^{35}$

They were of course exaggerating the history of conversion under Islam. The mere existence of so many minorities living peacefully under Ottoman rule should have showed the missionaries that their statement could not hold true. But this was less problematic than the fact that any Muslim who converted would be executed by the state. Despite this disturbing situation, the missionaries remained optimistic about their new field of labour and understood that they would only have to adjust to the new situation and change their priorities. Fisk and Parsons wrote:

All who are not Mahomedans are allowed to change their religion as they please, and to make what efforts they please to convert each other. The government never interferes [...] As to any molestation from the government, we feel almost as safe as we should in Boston. Should a Christian mission acquire considerable influence, it may attract notice; nor is it easy to predict what would be the consequences [...] There is reason to believe, that American missionaries will enjoy as much safety as merchants and other Christians who reside here and think of no danger. ${ }^{36}$

From this we learn that they understood that on foreign soil they could be well protected, in the beginning under the protection of the British

\footnotetext{
34) On the issue of conversion and apostasy, see Selim Deringil, “There Is No Compulsion in Religion': On Conversion and Apostasy in the Late Ottoman Empire: 1839-1856", in: Comparative Studies in Society and History 42 (2000), pp. 547-575.

35) Salibi/Khoury, The Missionary Herald, vol. 1, p. 15.

36) Ibid.
} 
consuls throughout the Empire (because the USA was not officially represented then). The missionaries clearly respected or feared Ottoman law significantly enough not to work against the ban on preaching to Muslims. What is more, they did not recognize the degree to which their mission would be changed because of this prohibition and that their target population would become the non-Protestant Christians living in "Greater Syria" (modern-day Syria, Lebanon, Jordan, Palestine and Israel).

Considering their eschalatogical view of history in the early $19^{\text {th }}$ century, they had four great expectations with regard to the Middle East: "(1) the global spread of the gospel; (2) the return of the Jews to Palestine and their 'restoration' (acceptance of Jesus Christ); (3) the fall of the Pope; and (4) the collapse of Islam". ${ }^{37}$

The American Protestants' mission in the Ottoman Empire, organized and funded by the ABCFM, later also acquired the role of an apostle for imperialism in the eventful $19^{\text {th }}$ century. Yet, at first their religious goals were expressed in apocalyptic terms, such as that the Gospel would "hasten the decline and fall of the bloody crescent of Mahommed" (1828) 38 and the "influx of light" caused by the missions in Syria would alarm the "Prince of Darkness" and lead "the Man of Sin" to double his efforts. Therefore "the Beast and the False Prophet occasionally unite" for opposing missionary efforts but this opposition would only be "a prelude to the battle of the great day" when Islam would be overthrown. ${ }^{39}$ As early as the late 1820 s those missionaries targeted Syria (including Palestine) as lands of the Bible ${ }^{40}$ that they reclaimed and gave attention to socially marginalized heterodox Muslim minorities such as the "Metawalies" (Shīi îs), Druzes and the "Anseiries" (Nuṣayrīs), who were not accepted by the Sunnī "Turks". These minorities who lived in the region stretching from Antioch to Palestine, a

\footnotetext{
37) Hans-Lukas Kieser, "Muslim Heterodoxy and Protestant Utopia. The Interactions between Alevis and Missionaries in Ottoman Anatolia", in: WI 41 (2001), pp. 89-111 (here p. 92); idem, "Mission as Factor of Change in Turkey (nineteenth to first half of twentieth century)", in: Islam and Christian-Muslim Relations 13 (2002), pp. 391-410 (here p. 393).

38) Salibi/Khoury, The Missionary Herald, vol. 2, pp. 7f.

39) Ibid., vol. 2, p. 195 (1830)

40) For a history of the missions in Syria and the Holy Land until 1854, see Harvey Newcomb, Cyclopedia of Missions (New York: Charles Scribner, 1854), pp. 733-743.
} 
"hiding place of schism and heresy", ${ }^{41}$ "though nominal Mohammedans, have scarcely any religion at all; and when the day comes, as it certainly will before long, that Mohammedans shall be converted to God, they will furnish a most interesting field of labor". By establishing the necessary missions also among the Muslims, especially the Druze and "the pagan Ansarrea", God would "hasten the downfall of Satan's empire throughout this land and the whole world". ${ }^{42}$

For the American Protestant missionaries the Nuṣayrīs were "a wretched and degraded people [...] for whom no evangelical exertions have been made" 43 and who were constantly oppressed by an unjust Ottoman government. ${ }^{44}$ What the Nuṣayrīs needed was "the word of life" ${ }^{45}$ They were "appropriate objects of christian benevolence" because

their religion, whatever it be, exerted no good influence upon them. It is in fact no better than paganism. Some of their ideas and many of their practices are truly abominable. Their women are in a most degraded condition, being regarded as incapable of religion, and treated almost like irrational creatures. Of course the ignorance and wretchedness of the people is very great. The way of peace they have not known. ${ }^{46}$

Initially the missionaries did not have much knowledge about the Nușayri people, in particular about their beliefs, except rumours. They regarded the Nușayrīs as hospitable and sociable, when it came to talk about their faith they were "much more willing to sip coffee and smoke tobacco, than to impart information about their country or their faith". The Nuṣayrīs had "hermetically sealed" their mouths due to fear of being hated and watched by the Muslims. ${ }^{47}$ One missionary neatly sums up this attitude with an Arabic proverb: "I talked to him to the east, and he answered to the west." ${ }^{48}$ Some basic information about the

\footnotetext{
41) Salibi/Khoury, The Missionary Herald, vol. 2, p. 149 (1829).

42) Ibid., vol. 2, p. 438 (1835).

43) Ibid., vol. 2, p. 292 (1831).

44) Samuel Lyde, The Asian Mystery: Ansaireeh or Nusairis of Syria (London: Longman, 1860), pp. 208ff.

45) Salibi/Khoury, The Missionary Herald, vol. 2, p. 316 (1832).

46) Ibid., vol. 3, p. 65 (1836).

47) Ibid., vol. 3, pp. 260f.; cf. pp. 267f. (1841).

48) Ibid., vol. 3, p. 269.
} 
Nuṣayrīs could be "ascertained", however: that they were numbering from 100,000 to 200,000; they were divided into different sects; they did not have places or times for prayers; they had feasts; there were no marriage laws (!); they had their own religious books; they believed in the transmigration of the soul; and they were illiterate. ${ }^{49}$ Eventually more information could be drawn about "this most miserable, ignorant and forsaken people", when missionaries travelled and lived among them they gathered statistics in the sixteen districts of Northern Syria with more than two thousand villages and the names of the chiefs in each district. According to another missionary, the Nuṣayrīs were the "chief attraction" for a mission in Syria and "would probably prove a very accessible people" because of the above-mentioned and also other reasons:

For generations they have seen no strangers or foreigners among them, except insulting enemies and outrageous oppressors. This has given them a distrust and a certain dislike of all strangers; but I am convinced that this would soon give way, and that the opposite feeling would be strongly awakened towards those who should come to them as steadfast and true friends [...] They spread all round the head of this sea [Mediterranean], and constitute the major part of the peasants on the great plains of Tarsus and Adana. Such a numerous, widespread, semi-barbarous and wholly neglected population present strong claims upon our Christian compassion; and if they are accessible to the missionary of the gospel, as there is reason to hope they will prove to be, ought they not to be looked after and provided for, with as little delay as possible? It is not a new, distant, inaccessible land. They are at the door, so to speak, of the mission now in the country. ${ }^{50}$

The missionaries felt proximity to the Nușayrīs not only because of compassion but also due to religious reasons: supposedly, this people did not practice Islam ("They are not Moslems") but seemed to be nearer to Eastern Christianity. ${ }^{51}$ When American Protestant missionaries first set foot on Ottoman soil, the two "most fanatical, bitter and zealous" opponents of Protestantism were Islam and Eastern Christianity. The original aim was to purify the nominal "degenerate" Christian

\footnotetext{
49) Ibid., vol. 3, p. 276 (1841). On p. 317 the number for Nuṣayrīs and Ismāêīīs in Syria is given as 200,000 .

50) Ibid., vol. 4, p. 6; report of Mr. Thomson, 1847.

51) Ibid.
} 
sects, revive their spiritual faith and make them preach the pure Gospel. Thus becoming true Christians and being united in one evangelical church, they would exert a vigorous influence on the Muslims with their righteousness. ${ }^{52}$ For this purpose, the Nuṣayrīs were sometimes seen as lost Christians and included among Christian denominations. ${ }^{53}$

The missionaries were convinced that the Nuṣayrīs were receptive to the Gospel and willing to receive missionaries and send their children to Protestant schools. They needed only to be convinced that "they [the missionaries] were sincere friends, and had come, not to rob, oppress and abuse them, but to befriend them and do them good". Their "ignorance and wretchedness, their utter destitution of religion, their isolation from all the rest of the world" were regarded as important factors to open missions among them. To bring "these miserable, outcast heathen, without God and having no hope" into the fold of Jesus was urgent and overdue..$^{54}$ All over, the Protestants of the ABCFM use the word "pagan" and "heathen" for groups that seemed not to be following Judaism, Christianity and Islam. In the words of Rufus Anderson, an outstanding minister at the Board, the word "heathen" was descriptive and not restrictive. ${ }^{55}$

Missionary schools were eventually established to educate those "who are destitute of the knowledge of Christianity". ${ }^{56}$ Besides nominal Christians and Jews, this included heterodox sects such as the Nuṣayrīs. Especially children needed to be taught the Bible. The main purpose of founding schools stemmed from the belief that by teaching the local youth, regardless of their religion, to read they would be able to choose

52) James Dennis, A Sketch of the Syria Mission (New York: Mission House, 1872), p. 5; Arthur J. Brown, Report of a Visitation of the Syria Mission of the Presbyterian Board of Foreign Missions (USA, 1902), p. 23; Joseph L. Grabill, Protestant Diplomacy and the Near East: Missionary Influence on American Policy, 1810-1927 (Minneapolis: University of Minnesota Press, 1971).

53) Brown, Report of a Visitation, p. 18; for a discussion, see Matti Moosa, Extremist Shiites: The Ghulat Sects (New York: Syracuse University Press, 1987), pp. $405 f$.

54) Salibi/Khoury, The Missionary Herald, vol. 4, pp. 18f. (1847).

55) Rufus Anderson, History of the Mission of the American Board of Commissioners for Foreign Missions to the Oriental Churches, 2 vols. (Boston: Congregational Publishing Society, 1872), vol. 1 , p. viii.

56) Ibid. 
the only "true" religion, i.e. Protestant Christianity. ${ }^{57}$ But only a few Nuṣayrīs converted to Protestantism; by the year 1868 American missionaries admitted that the Nuṣayrīs "have not been reached in any considerable numbers by the gospel", though some had become "enlightened" through the existence of a Protestant community near them. The missionaries still hoped that before long the evangelists "will have penetrated that section of the country, and that we shall begin to sap the foundations of Islam, among those who are less fanatically attached to all its precepts" ${ }^{58}$ The same hope prevailed later in 1911, when a missionary wrote that the schools they established in Nușayrī villages did not yield much fruit and so still few Nuṣayrīs converted to Protestantism, "some chosen ones who have received and lived the truth, despite the withering, blighting influence of the heathenism with which they have been surrounded". Efficient work was hindered by the "persistent and determined opposition" of the Ottoman government over the two previous decades, and the outcome was that "the darkness of ignorance, superstition and paganism still broods like a deadly miasma over the land, paralyzing the hearts and souls of men and casting over them the lethargy of spiritual death". ${ }^{59}$

On the whole the missionary project failed, not only in Syria; schools of the Syrian mission were closed down in the late 1880s until the early $1890 \mathrm{~s},{ }^{60}$ at the height of Sultan Abdülhamid II's power. Mehmed Ziya Bey, the local governor (mutasarrif) of Latakia from 1885 to 1892 (see below), is reported to have barred Protestant missionary work on behalf of the Ottoman government. Writing in November 1891, a missionary in Latakia stated that he "is doing all he can to hinder our work, seizing Mission property in Jendairia and Aldainey [two villages], turning our teachers out of doors and threatening them if they will not leave our employ". ${ }^{61}$ Henry Easson of the Reformed Presbyterian Church

\footnotetext{
57) Salibi/Khoury, The Missionary Herald, vol. 1, p. 45.

58) Ibid., vol. 5, p. 182.

59) J. M. Balph, "Among the Nussairyeh", in: Olive Trees, no. 8, August 1912 (journal of the Reformed Presbyterian Church), pp. 180-185 (here p. 184).

60) Julius Richter, A History of Protestant Missions in the Near East (London: Oliphant, 1910), p. 214; Douwes, "Knowledge and Oppression", in: Convegno sul tema La Shia, p. 166.

61) Private letter from Mary A. McCarroll, Herald of Mission News $1892-93$ (journal of the Reformed Presbyterian Church), p. 26.
} 
informed its board and the US State Department that the Ottoman government had illegally restored the mission property in Jendairia to its former Nuṣayrī owners in October 1891 and the following month their property in Aldainey was seized and the teachers were banned from the village. Mehmed Ziya had told him that since they did not own any building in the villages, they could not open schools. The governor had given orders to the village chiefs that they should not allow missionaries to enter the villages. ${ }^{62}$ The missionaries protested against the closing of the schools, saying that it is illegal because the Nuṣayrīs were "pagans" and not Muslims. ${ }^{63}$ What was injustice to the missionaries, was justice to the Nuṣayrīs, and deviant or heretical, for the Ottomans the Nuṣayrīs were still Muslims.

After decades of Ottoman oppression by several governors until the 1880 s, efforts were made later that decade to better their condition, ${ }^{64}$ though not out of sheer benevolence. Ismail Kemal Bey, governor general $(v \bar{a} l \bar{\imath})$ of Beirut from 1890 to 1892 , writes that he was struck by the injustices done to the Nuṣayrīs when he was inspecting the hinterland of Latakia and as a consequence introduced measures to appease them. It is worthwhile to fully quote him on this issue, as it serves as an example of the centralization policy of Abdülhamid II:

These mountaineers were as a race remarkable for their physical beauty, but, having been the objects of persistent persecution for centuries, they naturally felt but little sympathy for their neighbours. Rigorous measures had frequently to be taken against them by the Government; and every time there was need of repressive measures, these were accompanied by severity out of proportion to their misdeeds, and most of them, who took refuge in inaccessible mountains, lost their properties. When they returned after a certain length

62) Foreign Relations of the United States, United States Department of State, The executive documents of the House of Representatives for the second session of the fifty-second Congress. 1892-'93, vol. 1 (1892-1893), online at http://digicoll.library.wisc.edu/cgi-bin/FRUS/FRUS$i d x ? i d=$ FRUS.FRUS189293v01, pp. 563f., and vol. 2 (1893-1894), pp. 590f. (both accessed 19 May 2010). Apparently the missionaries got back the property in Aldainey in 1911 and reopened the school; see Balph, "Among the Nussairyeh", p. 182.

63) A. L. Tibawi, American Interests in Syria (Oxford: Clarendon Press, 1966), p. 262; Deringil, The Well-Protected Domains, p. 83.

64) Jens Hanssen, Fin de siècle Beirut: The Making of an Ottoman Provincial Capital (Oxford: Oxford University Press, 2005), pp. 68f. 
of time, these properties were returned to them, though they were no longer considered as the owners, but as tenants, and were compelled to pay rent. What was still worse was that these tenants of their own lands were forced into the bargain to pay taxes, like the actual proprietors! On learning the facts, I took steps to remedy this deplorable state of affairs by restoring their lands to them, and ordering the local authorities to treat them more justly in future, which I was sure would not only render them more contented, but would go far towards attaching them to the Government. ${ }^{65}$

The Latakia region was to be a "high-profile case" for carrying out the Ottomans' "benevolent reforms". ${ }^{66}$ Their "imperial reformation" in this period was not to bring liberty to subjects but to tighten the grip on them even more and firmly attach them to the central power. ${ }^{67}$ In order to prevent missionary work among heterodox sects Abdülhamid II pursued counter-propaganda through the establishment of Muslim schools and mosques in non-Sunnì areas. These were means of a "civilizing mission" by which "heretics" should be converted to the Hanafī school. A policy of reward and punishment or the "carrot-andstick method" was applied. ${ }^{68}$ Whereas sometimes brutal methods and systematic repression were used "to correct the ignorance and heresy of these people", often education and persuasion were applied as a "defensive weapon" against the imminent threat to the unity and integrity of the Ottoman Empire posed by these unorthodox communities. ${ }^{69}$ As it appears, sometimes groups of these marginal elements

65) Ismail Kemal Bey, The Memoirs of Ismail Kemal Bey, ed. by Sommerville Story (London: Constable \& Co., 1920), pp. 199 f.

66) Hanssen, Fin de siècle Beirut, p. 68.

67) Benjamin Fortna, Imperial Classroom: Islam, the State, and Education in the Late Ottoman Empire (Oxford: Oxford University Press, 2002), pp. 50-60; Makdisi, Artillery of Heaven, p. 208.

68) Deringil, The Well-Protected Domains, pp. 101f.; see further Ebubekir Ceylan, "Carrot or Stick? Ottoman Tribal Policy in Baghdad, 1831-1876", in: International Journal of Contemporary Iraqi Studies 3 (2009), pp. 169-186.

69) Deringil, "The Invention of Tradition", p. 17; Selçuk Akşin Somel, The Modernization of Public Education in the Ottoman Empire, 1839-1908: Islamization, Autocracy and Discipline (Leiden: Brill, 2001), pp. 222f. For the conversion policies among the Yezidis, see Edip Gölbaş1, The Yezidis and the Ottoman State: Modern Power, Military Conscription, and Conversion Policies, 1830-1909 (Ph.D. Thesis, Boğaziçi Üniversitesi, Istanbul, 2008); idem, “'Heretik' aşiretler ve II. Abdülhamid rejimi: Zorunlu askerlik meselesi ve ihtida 
converted to Hanafī-Sunnism willingly, as a response to Christian missionary activities. These would ask to be converted to the Hanafi school and request that schools and mosques be built in their district. Mehmed Ziya Bey ${ }^{70}$ warned Istanbul that if one leaves the Nușayrīs in a state of ignorance, this would only profit the missionaries "who have already gone so far as to pay regular salaries to the Nuṣayrī leaders". Therefore the Sultan should respond to the Nușayrī' wish to become Muslims and prove to the foreigners that their government is able to take care of them. ${ }^{71}$

One of the few Ottoman officials who seemed to have cared for the Nuṣayrīs was the liberal Midhat Pasha, governor general of Syria from 1878-1880. He had been already successful in carrying out various reforms in a brief span of time. Suspected later by Abdülhamid of being involved in the deposition and death of his uncle Sultan Abdülaziz (1876), Midhat was removed from Istanbul and put under the yoke of organizing state affairs in the problematic province of Syria that had seen inter-religious conflicts and several Nuṣayrī uprisings. When Midhat set out to reform the province, he presented petitions to the Sublime Porte, which the Syrian population welcomed. ${ }^{72}$ One of the steps to be taken was to pacify the Nuṣayrīs. According to al-Ṭawìl, an 'Alawì writer, due to his wisdom Midhat's initial suspicion of the rebellious Nuṣayrīs vanished soon, and he decided not to send troops to the Nuṣayrī mountains, as governors did before him. He summoned about

siyaseti odağında Yezidiler ve Osmanlı idaresi”, in: Tarih ve Toplum-Yeni Yaklaşımlar 9 (2009), pp. 87-156.

70) Deringil ("The Invention of Tradition", p. 15; and idem, Well-Protected Domains, p. 209, n. 87) and based on him, Ortaylı ("19. yüzyılda heterodox dinî gruplar", p. 159; "Nusayrîlik", p. 166) have misread the name as Muhammed Hassa.

71) BOA, İ.MMS. 114/4687, 13 Haziran 1306/26 June 1891, quoted in Deringil, "The Invention of Tradition", p. 15.

72) On his reform proposal for Syria, see Midhat Pasha, Suriye Lâyihası, ed. by Hüseyin Tosun (Istanbul: Matbaa ve Kütüphane-i Cihan, 1324/1906-07); in latinized form with introduction by Fethi Gedikli, "Midhat Paşa'nın Suriye Layihası", in: Divan (1999/2), pp. 169-189; see also BOA, Y.EE. 79/67, 12 Muharrem 1296/6 January 1879; BOA, Y.EE. 79/68, 4 Safer 1296/28 January 1879; and BOA, Y.EE. 79/92, 10 Receb 1297/18 June 1880. See further, Selçuk Günay, "II. Abdülhamid Döneminde Suriye ve Lübnan'da Arap Ayrılıkçı Hareketlerinin Başlaması ve Devletin Tedbirleri”, in: Ankara Universitesi Dil ve Tarih-Coğrafya Fakültesi Tarih Bölümü Tarih Araştırmaları Dergisi 17/28 (year?), pp. 85-108 (here pp. 95f.), online at http://dergiler.ankara.edu.tr (accessed 3 May 2010). 
five hundred Nuṣayrī leaders, notables and sheikhs alike, from all over Syria at a time when the region was in disarray and order needed to be restored. Midhat Pasha promised to save them from their bad situation and that they would be given a just administration which had been denied to them ever since. To further their progress and education, the governor wanted to open schools and build roads so their isolation would come to an end..$^{73}$ Midhat Pasha's project did not materialize; Abdülhamid removed him, thinking that his minister wanted decentralization in that region to increase his own power. ${ }^{74}$ Some governors after Midhat tried to continue with the education of the Nuṣayrīs.

According to 'Alawi writers ${ }^{75}$ several of their religious leaders tried to reform their faith and community during the awakening (yaqza) and renaissance (nabda) of the Nușayrīs in the $19^{\text {th }}$ century. The way they followed was to prove that the Nuṣayrīs were pious Muslims who adhered to Islamic rules. They believed that the only cure against the lethargy of their people was knowledge/science ('ilm). To achieve this, one of the sheikhs succeeded in meeting the abovementioned governor of Latakia, Mehmed Ziya Bey. ${ }^{76}$ It is said that he was convinced to take

\footnotetext{
73) Al-Ṭawìl, Ta'rīkh al-'Alawiyyin, pp. 308-312, 454-459; Moosa, Extremist Shiites, pp. $278 \mathrm{f}$.

74) For details of Midhat Pasha as governor of Syria, see, e.g., Ali Haydar Midhat, The Life of Midhat Pasha (New York: Arno Press, 1973, reprint of the 1903 edition published by Murray, London), pp. 178ff.; Najib Saliba, "The Achievements of Midhat Pasha as Governor of the Province of Syria, 1878-1880", in: IJMES 9 (1979), pp. 307-323; and Butrus AbuManneh, "The Genesis of Midhat Pasha's Governorship in Syria 1878-1880", in: Thomas Philipp/Birgit Schäbler (eds.), The Syrian Land: Processes of Integration and Fragmentation in Biläd al-Shäm from the 18th to the 20th Century (Stuttgart: Franz Steiner Verlag, 1998), pp. 251-267.

75) Maḥmūd al-Ṣalihh, al-Naba' al-yaqin 'an al-'Alawiyyin ("The Truth about the 'Alawīs"; Beirut: Bulagh, 1981); as the printed book was not at my disposal, I have used the online PDF version (n.p., n.d.) at http://www.myali.net/vb (accessed 15 March 2009). A Turkish translation is: Mahmud es-Sâlih, Gerçeklerin Işı̆ğında Alevîler (transl. Ahmed Bedir; Ankara: Baran, 2007). See also Sheikh 'Abd al-Rahmān al-Khayyir, Kitāb yaqzat al-muslimīn al-'alawiyyin ("The Book of the Awakening of the 'Alawi Muslims"), originally a series of articles published January to June 1937 in al-Nahda; for this see Kais M. Firro, "The 'Alawis in Modern Syria: From Nuṣayrīya to Islam via 'Alawìya”, in: Isl. 82 (2005), pp. 1-31 (here p. 26, n. 90). I had two online versions at my disposal at http://alaweenonline.com/content/ view/16/42/ and http://www.alaween.net/cms/modules/news/article.php?storyid=48 (both accessed 15 March 2009).

76) Al-Ṭawīl (Ta'rìkh al-'Alawiyyìn, pp. 312, 459), al-Ṣāliḥ (al-Naba' al-yaqìn 'an
} 
measures in order to save the Nuṣayrīs from ignorance and illiteracy. For this the sheikh wrote a tract to the Sublime Porte, which Ziya Bey forwarded. Istanbul was pleased and agreed. ${ }^{77}$ Other writers say that Ziya Bey emphasized in his letter the building of Sunnī schools and mosques as anti-propaganda against the Iranians who were using the Nuṣayrīs to encourage a revolt in the Ottoman Empire. ${ }^{78}$

Being a functionary of the Ottoman state and a devoted servant of Abdülhamid, Mehmed Ziya's version of the story is that several religious heads and secular leaders of the Nusayrīs approached and told him that in early times they had been pious Muslims but in the course of time strayed far from the right path because of ignorance. Now they wanted to awake from their "slumber of negligence" ( $k h \bar{a} b-\imath$ ghaflet) and see how the "matchless" Sultan Abdülhamid, like "a second conqueror" (fätih̆-i sānī), ${ }^{79}$ had spread sciences ('ulüm), education (ma'ärif) and justice ('adālet) in the Ottoman Empire and so "revived the people" (ahälīyi ihya à eylemişs). The Nușayrī leaders were proud of being attached to the Sultan, wanted to return to Islam and the Hanafì school and benefit from the sciences, education and the just order. Since they had "desired salvation" (necāt bulmak) the governor promised them instruction in the religion of Islam, sciences and education by carrying out the necessary measures, such as the construction of schools and mosques and providing elementary textbooks about Islamic principles. ${ }^{80}$

Schools and mosques were built in Nușayrī towns and villages but were abandoned after the death of Mehmed Ziya. ${ }^{81}$ They were used as

al-'Alawiyyin, pp. 113,127) and al-Khayyir wrongly state that the governor was the famous Ziya Pasha; he died in 1880 and was never mutașarrif of Latakia. Mehmed Ziya served as governor of Latakia from 1885-1892; see Douwes, "Knowledge and Oppression", in: Convegno sul tema La Shia, p. 167.

77) Al-Ṣāliḥ, al-Naba' al-yaqìn 'an al-'Alawiyyin, pp. 113f., $127 \mathrm{f}$.

78) Firro, "The 'Alawīs in Modern Syria", p. 14.

79) An allusion to the title fätih of Sultan Mehmed II.

80) BOA, İ.MMS. 113/4821, no. 7, 9 Mayıs 1306/21 May 1890; see also BOA, DH.MKT. 1823/38, 21 Şaban 1308/31 March 1891. The same was to be carried out for the Nuṣayrīs in Antakya and its environs; see BOA, DH.MKT. 1958/80, 12 Dhū l-Qa'da 1309/8 June 1892; BOA, DH.MKT. 2049/13, 18 Receb 1310/5 February 1893; BOA, DH.MKT. 31/9, 11 Rebiüssani 1311/22 October 1893.

81) BOA, MF.MKT. 77/10, 1 Şaban 1312/28 January 1895, states that primary (ibtida' $\bar{\imath})$ schools were abandoned. 
storage rooms and stables. ${ }^{82}$ "The result has been", according to the missionary Balph, "that a generation has grown up in ignorance." 83 And as Martin Kramer puts it, mosques had been built in Nuṣayrī areas "almost as talismans to ward off the foreign eye". ${ }^{84}$

On the whole, local Sunnīs viewed the Nuṣayrī conversions to Islam with suspicion, as they were allowed to hide their beliefs and appear as Muslims when forced by circumstances, meaning that they practiced taqiyya. ${ }^{85}$ There are reports of tens of thousands of Nușayrīs, such as in Antakya (1898), requesting conversion to Islam. ${ }^{86}$ Despite the Ottoman official policy accepting Nuṣayrī conversions, some meddlesome local notables and landowning families with influence in the region feared the decrease of their power and did not accept the Nuṣayrīs as Muslims. They also did not allow them entering mosques and schools. The reasons for not accepting the Nuṣayrīs as equal to the Sunnīs were that they continued with their corrupt beliefs; that they became Muslims only outwardly because then their testimony would be accepted in the courts, and-being farmers working on rented fields-they would lie under oath to each other and seize the fields on which they work. Moreover, the mufti of Antakya noted that even though the Nuṣayrīs adhered to the Islamic principles (bore testimony to Islam/şehädet, read the Qur'ān, etc.), they did this outwardly and hid their real beliefs; for this reason they should not be allowed to enter mosques. The mufti was dismissed by the Sublime Porte, saying that even if the Nuṣayrīs became Sunnīs outwardly, it did not matter, and they needed to be educated as good Muslims in order to abandon their previous corrupted beliefs. The fact that the Nuṣayrīs became Sunnīs also bothered some of their sheikhs.

\footnotetext{
82) Muhammad Farīd Wajdī, Dā'irat al-máārif li-l-qarn al-ishrīn, 10 vols. (Beirut: Dār al-Fikr, 1971); Halm, "Nușayriyya", p. 252; Moosa, Extremist Shiites, p. 279; Douwes, "Knowledge and Oppression", in: Convegno sul tema La Shia, p. 168. Still, around the same time and later in 1904 we see reports of Nuṣayrīs in Antakya asking for conversion and for schools; see, BOA, İ.MF.2/1311/R-1, 8 Ramazan 1311/15 March 1894; BOA, DH.MKT 866/56, 18 Ramazan 1822/26 November 1904.

83) Balph, "Among the Nussairyeh", p. 182.

84) Martin Kramer, Arab Awakening and Islamic Revival (New Brunswick/London: Transaction Publ., 2008), p. 191.

85) Douwes, "Knowledge and Oppression", in: Convegno sul tema La Shia, p. 167.

86) For mass conversions in Latakia, see BOA, İ.DH. 1306/1311/M-10, 12 Muharrem 1312/16 July 1894.
} 
The state ordered those sheikhs to be exiled for some time to places without Nuṣayrĩ inhabitants. ${ }^{87}$

The state deemed it politically incorrect that the Nuṣayrīs were not accepted as Sunnīs and should have separate mosques and schools as a different madhhab. As Christians were accepted to Islam without a question, the Nuṣayrīs too should be treated equally. Some opportunist individuals in Antakya, for instance, who wanted to employ the Nușayrīs as slaves in possession (birkaç menfa'at-perestānın ya'nī Nușayrī

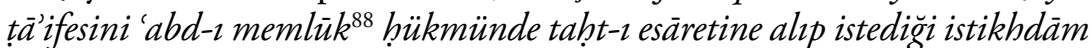
etmekte), prevented them to enter mosques. In order to avoid this, the state sent about 70-80 soldiers to the region and ordered some of those persons to Istanbul and rebuked them. The Sublime Porte thought that if the Nușayrīs were not accepted as Sunnīs, they would be easy targets for Protestant missionaries and eventually be converted, and so be protected by foreigners or apply to be exempted from military conscription as did non-Muslim subjects. ${ }^{89}$

In these cases, the central administration refused the protest by the people and the notables and accepted the Nuṣayrī conversions in order to reinforce Abdülhamid's position as caliph of all Muslims. ${ }^{90}$

On the whole, efforts by Midhat Pasha and well-intentioned officials after him to bring justice, education and welfare to the Nuṣayrī regions were not very successful. Before and after the Young Turk revolution Nuṣayrī leaders in Aleppo (1892) and Antakya and Latakia (1909) sent petitions to Istanbul and complained that despite the great number of their people, they were not represented in courts and councils. ${ }^{91}$ By and

87) Naim Ürkmez/Aydın Efe, "Osmanlı Arşiv Belgelerinde Nusayrîler Hakkında Genel Bilgiler", in: HBVAD 54, pp. 127-134 (here p. 130); Selahattin Tozlu, "Osmanlı Arşiv Belgelerinde Antakya ve İskenderun Nusayrîleri (19. Yüzyıl)”, in: ibid., pp. 79-110 (here p. 88).

88) For this technical term that occurs once in the Qur'ān, see A. J. Wensinck, "Mamlūk", in: $E I^{1}, 5$, p. 216.

89) BOA, DH.MKT. 31/9, 29 Ramazan 1310 (16 April 1893); Tozlu, “Osmanlı Arşiv", pp. $91 f$.

90) Deringil, The Well-Protected Domains, pp. 83f.; Somel, The Modernization of Public Education, p. 223; Ali Karaca, Anadolu ıslahatı ve Ahmet Şakir Paşa (Eren: Istanbul, 1993), p. 127.

91) The above cited BOA, Y.PRK.MF. 2/57, 5 Cemaziyelevvel 1310/24 November 1892, no. 1, p. 1; BOA, DH.MKT. 2739/90, 25 Muharram 1327/16 February 1909; BOA, DH.MKT. 2792/76, 27 Şubat 1324/12 March 1909. 
large, hostilities or unjust treatment by Sunnīs against the Nuṣayrīs seemed to have continued during the Young Turk era. ${ }^{92}$

As to the change from "Nuṣayrî" to "Alawī": most studies agree that the term "Alawi”" was not used until after WWI and probably coined and circulated by Muhammad Amīn Ghālib al-Ṭawīl, an Ottoman official and writer of the famous Ta'rikh al-'Alawiyyin (1924). In actual fact, the name "Alawî" appears as early as in an $11^{\text {th }}$-century Nuṣayrī tract as one the names of the believer (in al-Ṭabarānìs al-Dalä'il fì $m a^{\prime}$ 'rifat al-masä'il). Moreover, the term "Alawī" was already used at the beginning of the $20^{\text {th }}$ century. In 1903 the Belgian-born Jesuit and Orientalist Henri Lammens (d. 1937) visited a certain Haydarī-Nușayrī sheikh Abdullah in a village near Antakya and mentions that the latter preferred the name "Alawi”" for his people. ${ }^{93}$

Lastly, it is interesting to note that in the above mentioned petitions of 1892 and 1909 the Nuṣayrīs called themselves the "Arab 'Alawī people" ('Arab 'Alevī țā'ifesi), "our 'Alawī Nuṣayrī people" (țā'ifatunā al-Nusayriyya al-'Alawiyya) or "signed with 'Alawī people" ('Alevī țā'ifesi imżäsiyla). This early self-designation is, in my opinion, of triple importance. Firstly, it shows that the word "Alawi”" was always used by these people, as 'Alawi authors emphasize; secondly, it hints at the reformation of the Nușayrīs, launched by some of their sheikhs in the $19^{\text {th }}$ century and their attempt to be accepted as part of Islam; and thirdly, it challenges the claims that the change of the identity and name from "Nuṣayrî" to "Alawī" took place around 1920, in the beginning of the French mandate in Syria (1919-1938). ${ }^{94}$

\footnotetext{
92) For example in Antakya; BOA, DH.EUM.EMN. 80/21, 20 Receb 1332/14 June 1914.

93) Henri Lammens, "Une visite au šaih suprême des Nosairis Haidaris", in: Journal Asiatique XI:V (1915), pp. 139-159 (here p. 146).

94) For discussions, see al-Ṭawīl, Ta'rīkh al-'Alawiyyinn, pp. 448f.; Muhammad Kurd 'Alī, Khițat al-Shām, 6 vols. (Damascus: Mațba'at al-Mufĩd, 1928), vol. 6, pp. 265-268; al-Șālih, al-Naba' al-yaqin 'an al-'Alawiyyin, pp. 22-27, 45ff.; Moosa, Extremist Shiites, p. 280; Daniel Pipes, Greater Syria: The History of an Ambition (Oxford: Oxford University Press, 1990), p. 159; Firro, "The 'Alawis in Modern Syria", pp. 9-12; Yvette Talhamy, "The Fatwas and the Nusayri/Alawis of Syria", in: MES 46 (2010), pp. 175-194 (here p. 185); idem, "The Syrian Muslim Brothers and the Syrian-Iranian Relationship", in: MEJ 63 (2009), pp. 561580 (here p. 562); Gisela Procházka-Eisl/Stephan Procházka, The Plain of Saints and Prophets: The Nusayri-Alawi Community of Cilicia (Southern Turkey) and its Sacred Places (Wiesbaden: Harrasowitz, 2010), pp. 19-23 (esp. pp. 19f.).
} 
No doubt, the name "Alawi” became accepted after WWI with the short-lived "State of the 'Alawīs" (dawlat al-'Alawiyyin) under French mandate in Syria as an autonomous region and later as one of the "Federation States of Syria". ${ }^{95}$ It is common knowledge that the 'Alawis were made into a dominant sect by the French, who were trying to counter Sunni hegemony in Syria. The findings in this paper indicate that the 'Alawīs were already prepared for this role by the tension between the Ottomans and the Western Powers.

95) Procházka-Eisl/Procházka, The Plain of Saints and Prophets, p. 20. 